\title{
PERBANDINGAN PENINGKATAN HASIL BELAJAR MODEL PEMBELAJARAN KOOPERATIF TIPE COOPERATIVE SCRIPT DAN MAKE A MATCH
}

\author{
Tengku Sri Ulandari ${ }^{*}$, Husnarika Febriani ${ }^{1}$, Khairuna $^{1}$ \\ 1Universitas Islam Negeri Sumatera Utara \\ *tengkusriulandari27@gmail.com
}

\begin{abstract}
ABSTRAK
Dalam proses pembelajaran, seorang pendidik seharusnya menggunakan model pembelajaran yang beragam dalam kegiatan belajar mengajar di sekolah. Model pembelajaran memiliki peran penting dalam kegiatan pendidikan. Tujuan penelitian ini adalah untuk mengetahui perbandingan peningkatan hasil belajar siswa dengan menerapkan model pembelajaran kooperatif tipe cooperative script dan make a match pada materi sistem pernapasan manusia. Jenis penelitian ini merupakan penelitian tindakan kelas. Sampel penelitian ini adalah kelas VIII-6 yang terdiri dari 25 siswa dan VIII-7 yang terdiri dari 25 siswa. Model pembelajaran kooperatif tipe cooperative script diterapkan pada kelas VIII-6 dan model pembelajaran kooperatif tipe make a match diterapkan pada kelas VIII-7. Teknik pengumpulan data dilakukan dengan 4 cara yaitu; (1) tes (2) pengamatan (3) wawancara (4) dokumentasi. Teknik analisis data kuantitatif digunakan untuk menganalisis tingkat ketuntasan belajar, sedangkan analisis data kualitatif digunakan untuk mengetahui peningkatan hasil belajar siswa. Hasil penelitian menunjukkan bahwa model pembelajaran kooperatif tipe make a match memiliki peningkatan ketuntasan belajar klasikal yang lebih tinggi yaitu pada tahap pratindakan: 16\%, siklus I: 32\% dan siklus II: 92\% apabila dibandingkan dengan peningkatan ketuntasan belajar klasikal pada penerapan model pembelajaran kooperatif tipe cooperative script dengan jumlah pada tahap pratindakan: 12\%, siklus I: 28\% dan siklus II: 92\%. Saran untuk peneliti lain agar dapat melakukan perbandingan terhadap salah satu model pembelajaran yang diterapkan pada penelitian ini dengan berbagai model pembelajaran lainnya. Diharapkan agar pengetahuan terhadap berbagai perbandingan model pembelajaran dalam jenis penelitian tindakan kelas terus berkembang.
\end{abstract}

Kata Kunci: Cooperative Script, Hasil Belajar, Make A Match, Model Pembelajaran Kooperatif

\begin{abstract}
In the learning process, an educator should use a variety of learning models in teaching and learning activities at school. Learning models have an important role in educational activities. The aim of this study was to compare the improvement of student learning outcomes by applying cooperative learning types of cooperative script type and make a match on the human respiratory system topic. The type of this research was classroom action research. The sample was class VIII-6 consists of 25 students and VIII-7 consists of 25 students. The cooperative script of cooperative learning model was applied to class VIII-6 and the make a match was applied to class VIII-7. Data collection techniques were carried out in 4 ways, namely; (1) test, (2) observation, (3) interview, and (4) documentation. Quantitative data analysis techniques were used to analyze the level of mastery learning, while qualitative data analysis were used to analyze the improvement of learning outcomes. The results show that the make a match of cooperative learning model has a higher classical learning mastery improvement, namely at the pre-action stage: 16\%, cycle I: $32 \%$ and cycle II: 92\% when compared to the increase in classical learning completeness in the implementation of cooperative script of cooperative learning model by the percentage in the preaction stage: 12\%, cycle I: 28\% and cycle II: 92\%. It is suggest that knowledge of various comparisons of learning models in classroom action research will continue to develop.
\end{abstract}

Keywords: Cooperative Script, Learning Outcomes, Make A Match, Cooperative Learning Model

\section{PENDAHULUAN}

Keprofesionalitasan seorang guru sangat diperlukan dalam terciptanya proses pembelajaran kreatif, efektif, dan efisien untuk pengembangan kemampuan siswa yang memiliki karakteristik yang beragam berguna untuk 
meningkatkan hasil belajar jika proses pembelajaran terlaksana dengan baik (Siwi, 2020). Keberhasilan pembelajaran IPA dapat diukur dari keberhasilan siswa yang mengikuti kegiatan pembelajaran tersebut. Keberhasilan itu dapat dilihat dari tingkat pemahaman, penguasaan materi, serta hasil belajar siswa. Semakin tinggi pemahaman dan penguasaan materi serta hasil belajar maka semakin tinggi pula tingkat keberhasilan pembelajaran. Oleh karena itu, dalam proses pembelajaran dibutuhkan peningkatan hasil belajar dalam menunjang keberhasilan kegiatan belajar mengajar oleh guru terhadap siswa.

Dalam implementasinya, pendidik tidak dapat hanya mengandalkan satu model pembelajaran saja melainkan menggunakan model pembelajaran yang beragam dalam kegiatan belajar mengajar (KBM) di sekolah. Model menempati peranan yang tidak kalah pentingnya dari komponen lain dalam kegiatan pendidikan.

Model pembelajaran menempati peranan yang tidak kalah pentingnya dari komponen lain dalam kegiatan pendidikan. Tidak satupun kegiatan pendidikan yang tidak menggunakan model yang mencakup metode, dengan demikian maka setiap pendidik harus memahami kedudukan model sebagai alat motivasi ekstrinsik dalam kegiatan Pendidikan (Soiman, 2018). Khotimah dan Nuraida (2018) melaporkan bahwa ada peningkatan hasil belajar siswa dalam penerapan model pembelajaran cooperative script pada mata pelajaran IPA Biologi.

Pada hasil observasi awal di MTs Negeri dapat diketahui bahwa guru IPA di sekolah tersebut masih menggunakan model dan metode pembelajaran konvensional seperti metode diskusi, ceramah dan tanya jawab yang dianggap monoton menyebabkan siswa menjadi pasif dan kurang tertarik terhadap pelajaran IPA serta nilai rata-rata yang diperoleh siswa masih rendah yaitu dibawah 75 yang berarti tidak memenuhi nilai Kriteria Ketuntasan Minimal (KKM) siswa. Adapun nilai rata-rata ulangan harian siswa pada kelas VIII-6 yaitu 49,6 dan kelas VIII-7 yaitu 45,8. Sehingga dibutuhkan suatu tindakan dalam meningkatkan hasil belajar siswa yaitu dengan menerapkan model pembelajaran kooperatif tipe cooperative script dan make a match yang kemudian akan dilakukan perbandingan dari kedua tipe model pembelajaran tersebut.

Dalam pemilihan model pembelajaran sangat dipengaruhi oleh sifat dari materi yang akan diajarkan, tujuan yang akan dicapai dalam pembelajaran yang akan dilaksanakan, serta tingkat kemampuan peserta didik (Trianto, 2013). Model pembelajaran yaitu suatu rencana yang digunakan untuk membentuk rencana pembelajaran jangka panjang dengan merancang bahan-bahan pembelajaran. Pembelajaran kooperatif merupakan model pembelajaran yang menuntut siswa untuk aktif, kreatif, dan berlatih kemampuan bekerjasama, kemandirian, serta meningkatkan kemampuan berpikir tingkat tinggi (Purnamasari, 2014).

Tipe Make a Match melibatkan siswa secara langsung dalam proses pembelajaran, sehingga siswa lebih banyak memberikan perhatian dan lebih menikmati proses pembelajaran (Sirait \& Noer, 2013). Hal ini dikarenakan dalam tipe ini proses pembelajaran dibuat seperti sebuah permainan menggunakan kartu soal dan jawaban dengan tidak membuang esensi dari proses pembelajaran tersebut (Juhji, 2017). Tipe make a match juga merupakan salah satu model pembelajaran yang dapat diterapkan karena dalam proses pembelajaran ini siswa dapat mempelajari materi IPA dengan aktif dan menyenangkan (Wijanarko, 2017). Keunggulan dari tipe make a match ini yaitu siswa mencari pasangan kartu sambil belajar mengenai materi pembelajaran dalam suasana yang menyenangkan (Muntoha, 2013).

Sedangkan tipe cooperative script yaitu model belajar dimana siswa bekerja berpasangan dan secara lisan mengikhtisarkan bagian-bagian dari materi yang dipelajarinya dalam ruangan kelas (Aqib, 2013). Model pembelajaran kooperatif tipe cooperative script adalah model pembelajaran yang dapat meningkatkan daya ingat siswa (Rozi et al. 
2018). Hal ini sangat membantu siswa dalam mengembangkan serta mengaitkan fakta-fakta dan konsep-konsep yang pernah didapatkan dalam pemecahan masalah yang ada (Zico, 2018). Sehingga diharapkan siswa dapat memahami materi sistem pernapasan dengan baik dengan masing-masing model pembelajaran yang diterapkan.

\section{METODE}

Jenis penelitian ini merupakan penelitian tindakan kelas (classroom action research). Penelitian Tindakan Kelas (PTK) adalah suatu bentuk penelitian yang bersifat reflektif dengan melakukan tindakan-tindakan tertentu agar dapat memperbaiki dan meningkatkan praktikpraktik pembelajaran di kelas secara profesional (Masnur, 2011; Muslich, 2011; Sanjaya, 2009). Teknik pengambilan sampel yaitu cluster random sampling (sampel berkelompok), dalam artian setiap subjek dalam populasi memperoleh kesempatan dipilih menjadi sampel (Sugiono, 2010). Sampel penelitian ini berjumlah 50 siswa, yang terdiri dari 25 siswa di tiap kelasnya. Pada kelas VIII-6 diterapkan model pembelajaran kooperatif tipe cooperative script dan kelas VIII-7 diterapkan model pembelajaran kooperatif tipe make a match. Teknik pengumpulan data dilakukan dengan 4 cara yaitu; (1) tes. Tes hasil belajar yang digunakan disusun dalam bentuk soal multiple choice atau pilihan ganda terdiri dari 10 soal. (2) pengamatan/ observasi. Observasi merupakan teknik mengumpulkan data dengan cara mengamati setiap kejadian yang sedang berlangsung dan mencatatnya dengan alat observasi tentang hal-hal yang akan diamati atau diteliti (Wina, 2009). wawancara terhadap guru (4) dokumentasi. Analisis data kuantitatif digunakan untuk menganalisis tingkat ketuntasan belajar. Sedangkan analisis data kualitatif digunakan untuk mengetahui peningkatan hasil belajar siswa. Keduanya didapatkan dari hasil tes, wawancara dan observasi yang telah dilaksanakan yang dijelaskan berbentuk narasi.

\section{HASIL DAN PEMBAHASAN Cooperative Script}

Pada siklus I dan II, observasi dilakukan bersamaan dengan proses pelaksanaan tindakan, yaitu pada pembelajaran di kelas secara langsung. Peneliti bertindak sebagai guru dan pengamat proses pembelajaran yang dilakukan. Berdasarkan hasil observasi I terhadap siswa maka dapat diketahui beberapa siswa memperhatikan penjelasan guru. Siswa mulai sedikit aktif dan mulai mampu bekerjasama dengan teman sekelompoknya dan sedikit bagus dalam mempresentasikan hasil diskusinya (saat bertukar peran).

Sedangkan pada siklus II dapat diketahui bahwa siswa sangat antusias dan serius dalam memperhatikan penjelasan guru saat proses pembelajaran berlangsung, siswa aktif dan mampu berinteraksi dengan baik kepada teman yang bertugas bertukar peran dengannya (pembicara dan pendengar) dan mempresentasikan atau menjelaskan hasil ringkasannya.

\section{Make A Match}

Pada Siklus I, observasi dilakukan bersamaan dengan proses pelaksanaan tindakan, yaitu pada pembelajaran di kelas secara langsung. Peneliti bertindak sebagai guru dan pengamat proses pembelajaran yang dilakukan. Berdasarkan hasil observasi I terhadap siswa maka dapat diketahui

beberapa siswa memperhatikan penjelasan guru dalam proses pembelajaran, beberapa siswa juga mulai sedikit aktif dan bekerja sama serta 8 orang diantara siswa berhasil menemukan pasangan dari kartunya dalam waktu yang telah ditentukan guru.

Sedangkan pada siklus II dapat diketahui bahwa siswa sangat serius dalam memperhatikan dan mendengarkan penjelasan dan arahan guru saat proses pembelajaran, siswa aktif dan mampu berkerjasama dengan siswa lainnya serta banyak siswa yang berhasil menemukan pasangan kartu yang sesuai dengan kartu yang dipengangnya (kartu soal/kartu jawaban). 


\section{Hasil Belajar}

Hasil belajar diperoleh dari soal pretest dan posttest berbentuk pilihan berganda sebanyak 10 soal yang diberikan kepada siswa pada setiap siklusnya. Kemudian dianalisis secara kuantitatif dan kualitatif dan diperoleh nilai rata-rata siswa, jumlah siswa yang tuntas dan tidak tuntas serta ketuntasan belajar klasikal siswa seperti pada Tabel 1.

Tabel 1. Rekapitulasi hasil belajar IPA siswa (pratindakan, siklus I dan siklus II) dengan menerapkan model pembelajaran kooperatif tipe cooperative script di kelas VIII-6 dan tipe make a match di kelas VIII-7

\begin{tabular}{|c|c|c|c|c|c|c|c|c|c|}
\hline \multirow{3}{*}{ No } & \multirow{3}{*}{ Kegiatan } & \multirow{2}{*}{\multicolumn{2}{|c|}{$\begin{array}{c}\text { Nilai } \\
\text { Rata-Rata }\end{array}$}} & \multicolumn{4}{|c|}{ Jumlah Siswa } & \multirow{2}{*}{\multicolumn{2}{|c|}{$\begin{array}{c}\text { Ketuntasan Belajar } \\
\text { Klasikal }\end{array}$}} \\
\hline & & & & \multicolumn{2}{|c|}{$\mathrm{CS}$} & \multicolumn{2}{|c|}{ MAM } & & \\
\hline & & $\mathrm{CS}$ & MAM & $\mathrm{T}$ & $\mathrm{TT}$ & $\mathrm{T}$ & $\mathrm{TT}$ & $\mathrm{CS}$ & MAM \\
\hline 1 & Pra Tindakan & 51,2 & 45,2 & 3 & 22 & 4 & 21 & $12 \%$ & $16 \%$ \\
\hline 2 & Siklus I & 60,4 & 65,2 & 7 & 18 & 8 & 17 & $28 \%$ & $32 \%$ \\
\hline 3 & Siklus II & 82,8 & 83,6 & 23 & 2 & 23 & 2 & $92 \%$ & $92 \%$ \\
\hline
\end{tabular}

Nilai rata-rata siswa pratindakan yaitu 51,2 yang kemudian meningkat setelah adanya tindakan (penerapan model pembelajaran kooperatif tipe cooperative script) pada siklus I menjadi 60,4 dengan jumlah siswa yang tuntas awalnya 3 orang menjadi 7 orang dan siswa yang tidak tuntas berjumlah 22 siswa menjadi 18 siswa. Setelah diberikan tindakan pada siklus II nilai rata-rata siswa meningkat menjadi 82,8 dari nilai rata-rata siklus I dengan jumlah siswa yang tuntas menjadi 23 siswa dan yang tidak tuntas berjumlah 2 orang. Sedangkan ketuntasan belajar klasikal siswa pada pratindakan sebesar $12 \%$, siklus I sebesar 28\% dan siklus II sebesar $92 \%$.

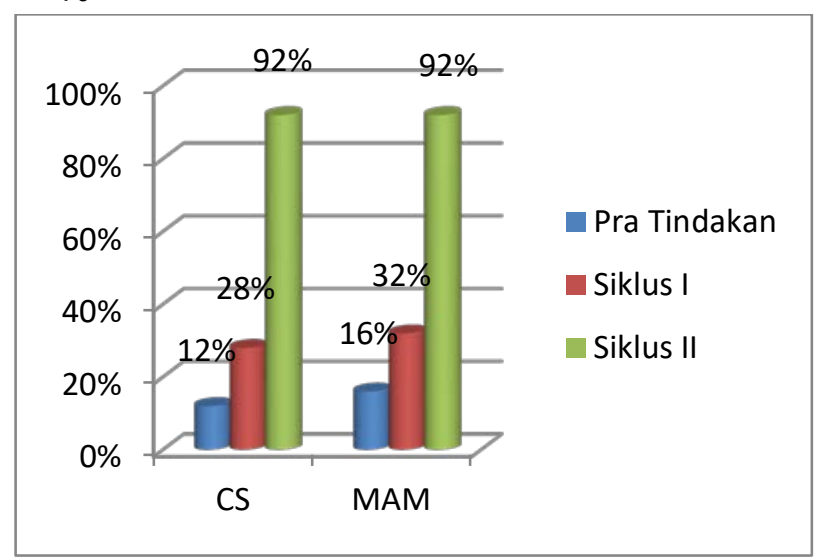

Gambar 1. Diagram perbandingan nilai rata-rata siswa

Nilai rata-rata siswa pratindakan yaitu 45,2 yang kemudian meningkat setelah adanya tindakan (penerapan model pembelajaran kooperatif tipe make a match) pada siklus I menjadi 65,2 dengan jumlah siswa yang tuntas awalnya 4 orang menjadi 8 orang dan siswa yang tidak tuntas berkurang dari 21 siswa menjadi 17 siswa. Setelah diberikan tindakan pada siklus II, nilai rata-rata siswa meningkat menjadi 83,6 dari nilai rata-rata siklus I dengan jumlah siswa yang tuntas menjadi 23 siswa dan yang tidak tuntas berjumlah 2 orang. Sedangkan ketuntasan belajar klasikal siswa pada pratindakan sebesar $16 \%$, siklus I sebesar 32\% dan siklus II sebesar $92 \%$.

Model pembelajaran koperatif tipe make a match memilki peningkatan ketuntasan belajar klasikal yang lebih tinggi yaitu pada tahap pratindakan sebesar 16\%, siklus I sebesar 32\% dan siklus II sebesar 92\% apabila dibandingkan dengan peningkatan ketuntasan belajar klasikal pada penerapan model pembelajaran kooperatif tipe cooperative script dengan jumlah pada tahap pratindakan sebesar $12 \%$, siklus I sebesar $28 \%$ dan siklus II sebesar 92\%. Hal ini terjadi karena model pembelajaran kooperatif tipe make a match merupakan model pembelajaran yang menyenangkan.

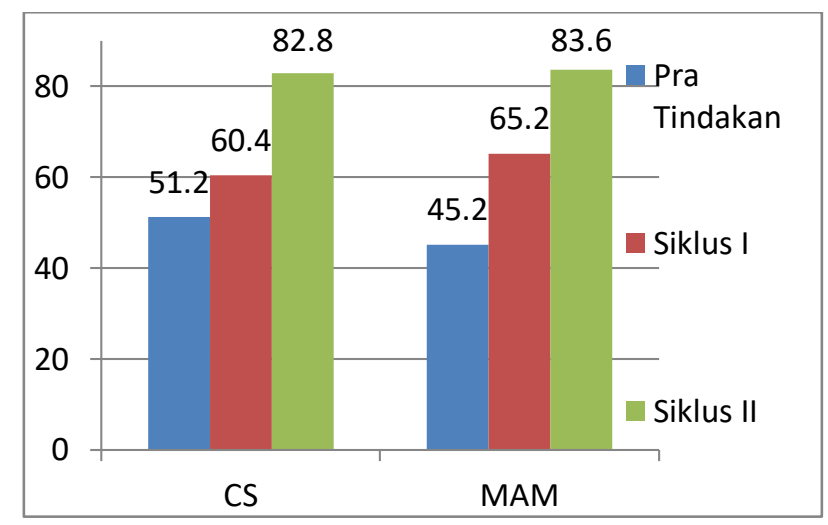

Gambar 2. Diagram perbandingan ketuntasan belajar klasikal siswa 
Rekapitulasi nilai rata-rata dan ketuntasan belajar klasikal siswa dapat dilihat pada diagram di atas. Jadi, berdasarkan model pembelajaran yang diterapkan yaitu model pembelajaran kooperatif tipe make a match memilki peningkatan ketuntasan belajar klasikal yang lebih tinggi yaitu pada tahap pratindakan sebesar $16 \%$, siklus I sebesar 32\% dan siklus II sebesar 92\% apabila dibandingkan dengan peningkatan ketuntasan belajar klasikal pada penerapan model pembelajaran kooperatif tipe cooperative script dengan jumlah pada tahap pratindakan sebesar 12\%, siklus I sebesar 28\% dan siklus II sebesar 92\%. Hal ini terjadi karena model pembelajaran kooperatif tipe make a match merupakan model pembelajaran yang menyenangkan. Hal ini sejalan dengan pendapat Setyaningsih (2016) mengenai kelebihan model pembelajaran ini yaitu Model pembelajaran kooperatif tipe make a match menghindari kejenuhan siswa dalam mengikuti kegiatan belajar mengajar dan pembelajaran lebih menyenangkan karena melibatkan media pembelajaran yang dibuat oleh guru (Setyaningsih, 2016).

Pada hasil tes siklus II diperoleh hasil ketuntasan belajar klasikal siswa yang sama pada penerapan kedua tipe model pembelajaran kooperatif yaitu tipe cooperative script dan make a match sebesar 92\% (tergolong sangat tinggi). Dengan nilai rata-rata pada penerapan model pembelajaran kooperatif tipe cooperative script 82,8 dan make a match 83,6. Khotimah \& Nuraida (2018) dan Nur \& Dede (2018) melaporkan bahwa ada peningkatan hasil belajar siswa dalam penerapan model pembelajaran cooperative script pada mata pelajaran IPA Biologi. Pada siklus I diperoleh rata-rata 70 dengan persentase ketuntasan klasikal sebesar $62,5 \%$ dengan kualifikasi efektif dan pada siklus II diperoleh data persentase ketuntasan klasikal 83,3\% dengan kualifikasi sangat baik.

Dalam keberhasilan penelitian ini tentunya banyak unsur yang menjadi faktor pendukung. Namun, dalam proses pelaksanaan penelitian juga memiliki berbagai hambatan dalam mencapai keberhasilan penelitian ini.

\section{Faktor Pendukung Guru Mata Pelajaran IPA}

Dalam proses penelitian ini guru sangat antusias dan terus memberikan arahan kepada peneliti dalam melakukan tindakan penelitian. Oleh sebab itu keberhasilan penelitian ini juga sangat berpengaruh oleh guru yang biasa mengajar mata pelajaran IPA di sekolah tersebut.

\section{Peneliti}

Dalam penelitian ini, peneliti bertindak sebagai seorang guru. Seorang guru sangat berperan penting dalam meningkatkan hasil belajar siswa. Dalam meningkatkan hasil belajar siswa peneliti yang bertindak sebagai guru menerapakn model pembelajaran kooperatif tipe cooperative script dan make a match. Sehingga dapat dikatakan peneliti mempunyai faktor pendukung dalam mempersiapkan perencanaan pembelajaran yang matang dan mampu meningkatkan hasil belajar siswa.

\section{Peserta Didik/Siswa}

Pada awal penelitian siswa terlihat masih belum aktif dan hanya beberapa yang memperhatikan proses pembelajaran berlangsung. Namun pada pelaksanan tindakan siklus selanjutnya terjadi peningkatan terhadap hasil belajar siswa. Sehingga siswa mencapai ketuntasan keberhasilan klasikal yang diperoleh tergolong sangat tinggi.

\section{Letak Sekolah}

Letak sekolah yang strategis dan jauh dari keramaian auara kendaraan dan masyarakat membuat proses pembelajaran berlangsung dengan baik.

\section{Faktor Penghambat}

Menurut Husnul (2020), pandemi COVID-19 mengakibatkan lamanya penelitian berlangsung. Pada saat pandemi semua peserta didik diharuskan melakukan pembelajaran secara daring (dalam jaringan). Pada penelitian ini diketahui keputusan dari pihak sekolah terhadap pertemuan proses pembelajaran secara tatap muka hanya berlaku seminggu sekali, selain itu proses pembelajaran dilakukan secara daring atau belajar dari rumah secara online. Oleh karena itu, penelitian dilakukan dengan satu kali 
pertemuan setiap siklusnya atas dasar perizinan dari pihak sekolah (kepala sekolah dan guru mata pelajaran IPA). Namun, dalam hal ini pengaturan waktu penelitian dalam proses pembelajaran berlangsung baik.

\section{PENUTUP}

Model pembelajaran kooperatif tipe make a match memiliki peningkatan ketuntasan belajar klasikal lebih tinggi yaitu pada tahap pratindakan sebesar 16\%, siklus I sebesar 32\% dan siklus II sebesar 92\% apabila dibandingkan dengan peningkatan ketuntasan belajar klasikal pada penerapan model pembelajaran kooperatif tipe cooperative script dengan jumlah pada tahap pratindakan sebesar $12 \%$, siklus I sebesar $28 \%$ dan siklus II sebesar 92\%. Hal ini terjadi karena model pembelajaran kooperatif tipe make a match merupakan model pembelajaran yang menyenangkan.

Faktor pendukung penelitian diantaranya adalah guru mata pelajaran IPA yang sangat antusias dan terus memberikan arahan kepada peneliti, dimana peneliti bertindak sebagai seorang guru yang berperan penting dalam meningkatkan hasil belajar siswa dengan menerapkan model pembelajaran kooperatif tipe cooperative script dan make a match. Faktor lainnya adalah letak sekolah yang strategis dan jauh dari keramaian suara kendaraan dan masyarakat membuat proses pembelajaran berlangsung dengan baik. Sedangkan faktor penghambat yaitu keadaan pandemi COVID-19 yang berpengaruh terhadap waktu maupun pelaksanaan penelitian.

Saran untuk peneliti lain agar dapat melakukan perbandingan terhadap salah satu model pembelajaran yang diterapkan pada penelitian ini dengan berbagai model pembelajaran lainnya. Sehingga pengetahuan terhadap berbagai perbandingan model pembelajaran dalam jenis penelitian tindakan kelas dapat berkembang.

\section{REFERENSI}

Aqib, Z. (2013). Model-model, media, dan strategi pembelajaran kontekstual (inovatif). Yrama Widya.

Khotimah, H. (2020). Meningkatkan hasil belajar peserta didik menggunakan strategi story board pada mata pelajaran akidah akhlak di kelas VIII MTs Nurul Himkah Tinjoan, [Skripsi]. UIN Sumatera Utara.

Juhji. (2017). Model pembelajaran kooperatif tipe make a match dalam pembelajaran IPA. Jurnal Primary, 9(1), 9-16.

Muslich, M. (2011). Melaksanakan PTK itu mudah (classroom action research); Pedoman praktis bagi guru profesional. PT Bumi Aksara.

Nur, K. E \& Dede, N. (2018). Penerapan model pembelajaran cooperative script untuk meningkatkan hasil belajar siswa pada mata pelajaran IPA Biologi. Proceeding Biology Education Conference, 15(1), 159- 164.

Purnamasari, Y. (2014). Pengaruh model pembelajaran kooperatif tipe teams games tournament (TGT) terhadap kemandirian belajar dan peningkatan kemampuan penalaran dan koneksi matematik peserta didik SMPN 1 Kota Tasikmalaya. Jurnal Pendidikan dan Keguruan, 1(1), 68-77.

Rozi, F., Harmoko \& Ferty L T. (2018). Model cooperative script terhadap aktivitas dan hasil belajar biologi siswa kelas VIII SMP Negeri 7 Lubuklinggau. Jurnal Pendidikan Biologi dan Sains (Bioedusains), 1(1), 23-33.

Sanjaya, W. (2009). Penelitian Tindakan Kelas. Kencana.

Setyaningsih. (2016). Penerapan model pembelajaran kooperatif tipe make a match untuk meningkatkan hasil belajar IPA siswa kelas VI SD Negeri 006 Tri Mulya Jaya Kecamatan Ukui. Jurnal Primary, 5(3), 317330.

Sirait, M., \& Noer, P. A. (2013). Pengaruh model pembelajaran kooperatif tipe make a match terhadap hasil belajar siswa. INPAFI, 1(3), 252-259.

Siwi, P \& Nuraini, D. (2020). Efektivitas model cooperative learning tipe make a match terhadap hasil belajar ipa pada siswa kelas $\mathrm{V}$ SD Muhammadiyah Karangploso. Jurnal Taman Cendekia, 4(1), 445-451. 
Tengku Sri Ulandari \& Khairuna, Perbandingan Peningkatan Hasil Belajar Model Pembelajaran Kooperatif Tipe Cooperative Script dan Make a Match

Jurnal Biolokus: Jurnal Penelitian Pendidikan Biologi Dan Biologi Vol.4 (1)

Soiman. (2018). Metode Pendidikan Rasulullah

SAW: Tela'ah Kitab Shahih Bukhari dan

Shahih Muslim. Perdana Publishing.

Sugiono. (2010). Metode Peneltian kuantitatif, kualitatif dan R\&D. Alfabeta.

Trianto. (2013). Mendesain model pembelajaran inovatif, progresif, konsep, landasan, dan implementasinya pada kurikulum tingkat satuan pendidikan (KTSP). Kencana Prenada Media Group.

Wijanarko, Y. (2017). Model pembelajaran make a match untuk pembelajaran IPA yang menyenangkan. Jurnal Taman Cendekia, 1(1), 52-59. 